\title{
New Recorded of Saltwater Crocodile Crocodylus porosus Schneider, 1801 from East Coast Mangrove Ecosystem in Surabaya, East Jawa, Indonesia
}

\author{
Sapto Andriyono $^{1^{*} \mathrm{O} \text {, and Agustin Sukistyanawati }}{ }^{2}$ \\ ${ }^{1}$ Department of Marine, Fisheries and Marine Faculty, Universitas Airlangga C Campus Jl. \\ Mulyorejo Surabaya East Java, 60115, Indonesia \\ ${ }^{2}$ The East Java Conservation of Natural Resources Agency, J1. Raya Bandara Juanda Sidoarjo \\ East Java 61253, Indonesia \\ "Corresponding authors: sapto.andriyono@fpk.unair.ac.id
}

Submitted: 02 July 2021 Revised: 04 October 2021 Accepted: 11 October 2021 Publish: 30 October 2021

\begin{abstract}
.
A single specimen of saltwater crocodile Crocodylus porosus Schneider, 1801 (1.50 cm in length) was captured and photographed by a local fisherman by gill net at fishpond around mangrove ecosystem of east coast Surabaya on December 2020. The location where the estuarine crocodile caught is an important wetland area in Surabaya with an excellent mangrove cover. Wonorejo mangrove location is about $10 \mathrm{~km}$ from the center of Surabaya, the second-largest city in Indonesia. This finding is considered as a first reported of $C$. porosus in Surabaya, and at the same time is proof of the importance of the mangrove area on the east coast of Surabaya as a habitat for wildlife that must be conserved appropriately. Routine monitoring of mangrove areas, including their wildlife, is essential so that they are not displaced by the development of the city which changes the land function to become a residential area.
\end{abstract}

Keywords: Saltwater crocodile, endangered, wildlife, Wonorejo

\section{Introduction}

The saltwater crocodile (C. porosus Schneider, 1801) is one of 4 types of crocodiles that live in Indonesian waters and are protected by law in Indonesia (Iskandar 2000, Kurniati 2008). Based on several references, this crocodile population in Indonesia has never been surveyed in detail, but in some areas, it is still found in the wild, especially in the National Park area, which still has good enough habitat to breed crocodiles. An extensive crocodile survey program was carried out by the FAO and the Directorate General of Forest Protection and Nature Conservation (PHKA) in the 1990s. However, it does not produce estimates of the population or distribution of estuarine crocodiles throughout Indonesia (Webb, Manolis et al. 2010). In some areas in Indonesia, the Kalimantan

region has the most records of saltwater crocodiles, such as East Kalimantan and East Nusa Tenggara. This crocodile type is still easily found in three conservation areas: Teluk Kupang Marine Nature Tourism Park, Menipo Nature Tourism Park, and Maubesi Mangrove Forest Nature Reserve (Saragih, Hidayatullah et al. 2020). Another hand, captive breeding has been carried out in Samarinda, East Kalimantan, to maintain the existence of crocodile species estuary (Ripai and Kamarubayana 2016).

Based on the Regulation of the Minister of Environment and Forestry Number P.20/2018 concerning protected types of plants and animals, saltwater crocodiles are included in the list of protected animals in Indonesia in Appendix II and Appendix I (Webb, 
Manolis et al. 2010). However, function of an ecosystem (Hines and exploration activities are still possible by Gessner 2012). However, the presence of exerting captivity and breeding for saltwater crocodiles in the mangrove area commercial purposes with very tight of Surabaya has not been studied. permits and supervision. As reptiles that Changes in function and area into various grow to a maximum length of up to 6- $7 \mathrm{~m}$ human activities have become the leading (Whitaker 2008, Webb, Manolis et al. 2010, Britton, Whitaker et al. 2012), these animals become one of the top predators in aquatic ecosystems that maintain ecosystem balance (Thorbjarnarson 2010) cause of the loss of crocodile habitat in Indonesia. Apart from habitat loss, changes in the area will also affect the availability of food and a place to breed so that the crocodile population will decline. and able to change the structure and

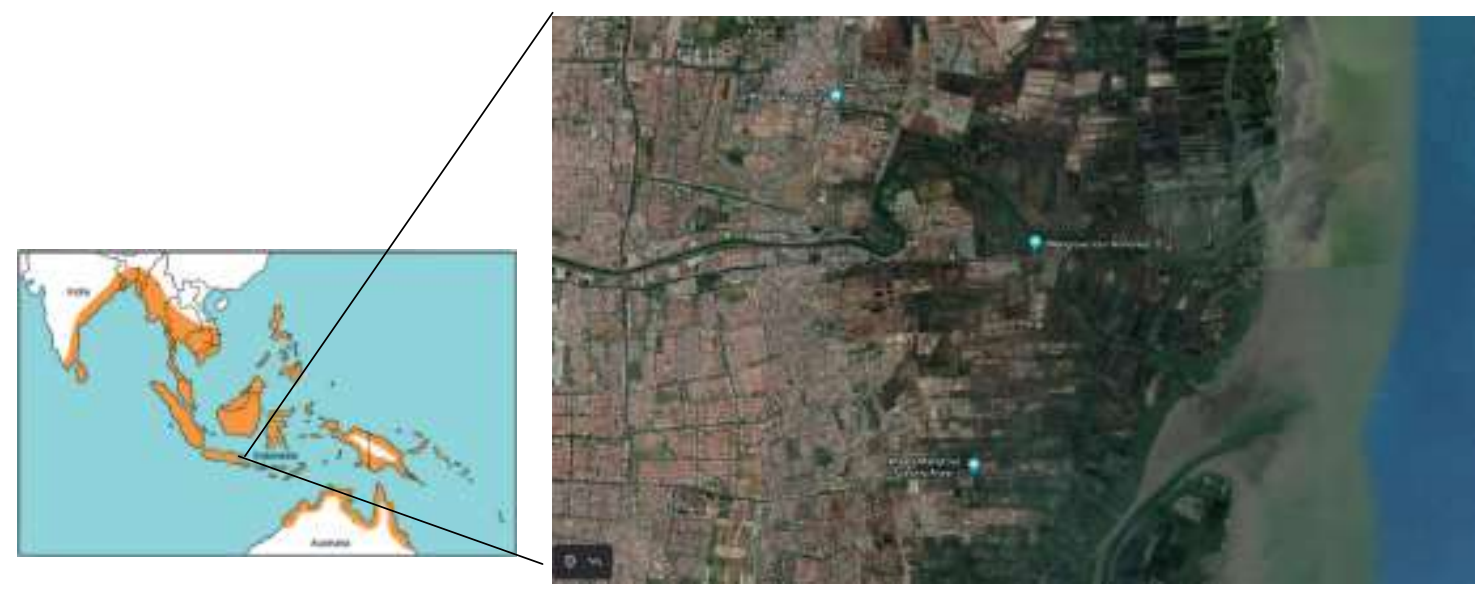

Figure 1. Map of distribution C. porosus around Southeast Asia (insert) (Webb, Manolis et al. 2010), location fishpond in Wonorejo including a green belt (mangrove ecosystem) of the east coast Surabaya, East Java (https://earth.google.com/).

\section{Materials and Methods}

We captured a single specimen by local fisherman using a gill net on December 2020 in Wonorejo Village which included in the east coast of Surabaya, East Java Province $\left(7^{\circ} 18^{\prime} 02^{\prime \prime} \mathrm{S} ; 112^{\circ} 48^{\prime} 31 " \mathrm{E}\right)$ (Fig. $1)$. The crocodile was documented and photographed, although no voucher specimen was retained because this reptile and directly handle by Natur Conservation Agency of East Jawa Province (BBKSDA). Based on morphological characteristic of this single specimen were analyzed following FAO identification manual (Carpenter and Niem 2001). 


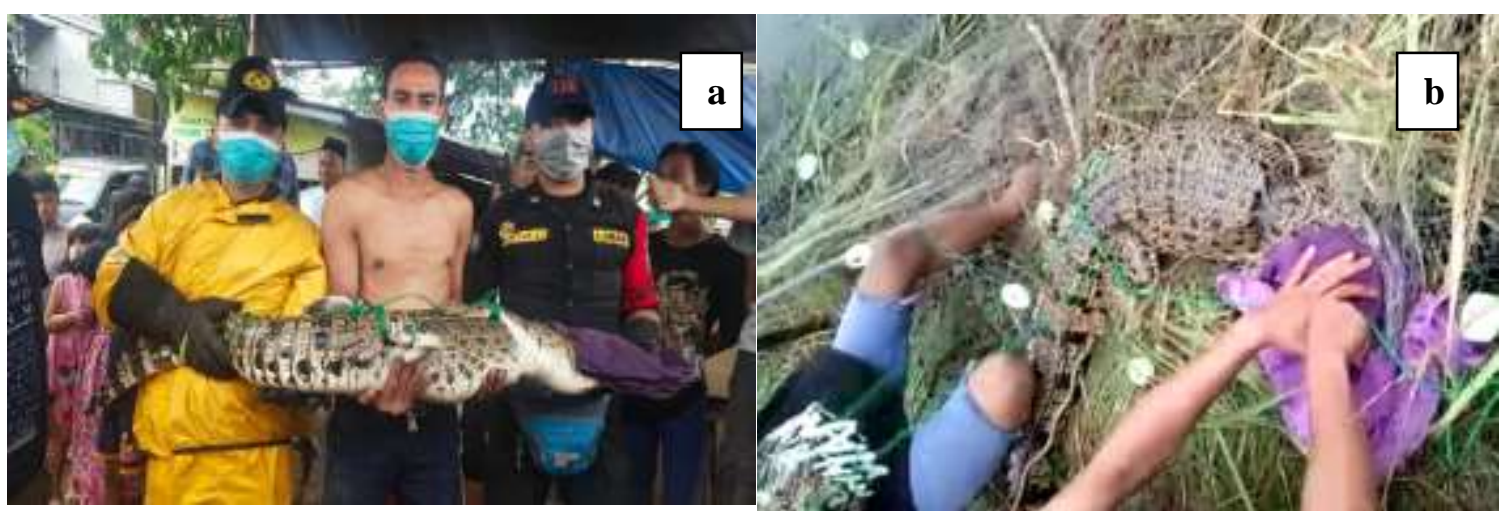

Figure 2. a:Angga and two Linmas officers with the saltwater crocodile before sending to the Surabaya Zoo (https://news.detik.com/ ), b: Evacuation process from fishpond which trap of saltwater crocodile Crocodylus porosus at gill net of local fisherman

RESULTS AND DISCUSSION

Surabaya, which is currently the second-largest city after Jakarta, still has a coastal wetland ecosystem in the form of a mangrove ecosystem. This ecosystem is scattered along the eastern area of Surabaya, which currently has developed into many residential areas and other uses. The area of the mangrove area in Surabaya is estimated at 2,503.9 ha which has the potential to store many wild animals such as to monitor lizards, longtailed monkeys (Anggraeni, Rinaldi et al. 2013), and various migratory birds (Suwarti, Mulyani et al. 2018) that forage for food and breed in this area. From several reports collected, the discovery of crocodiles in the Wonorejo mangrove area has become a new record for estuarine crocodiles in Surabaya.

Although the folklore that develops about the legend of the city of Surabaya is very thick with figures of crocodiles and sharks, in reality, there are no reports that mention crocodiles in the coastal area of Surabaya. This situation was changed by the findings on December 11, 2020. found a crocodile with a size close to 1.5 meters in length that entered the traditional fish pond. Although only a single species was found, the authors estimate that there are still more crocodiles inhabiting this area.

The characteristics of a saltwater crocodile (Crocodylus porosus Schneider, 1801), among others, can be identified easily by paying attention to several parts of its body such as the head, ventral, lateral and caudal parts. The scales on the back of the head (post occipital scute) in estuarine crocodiles are very characteristic, with numbers ranging from 4-6 units. On the lateral and dorsal side, there is a smooth scute row. There is a black belt with less than 28 ventral scales (Kurniati 2008). All the distinctive characters of Crocodylus porosus can be found clearly in this crocodile caught in Wonorejo (Fig 2a and Fig 2b). The existence of estuarine crocodiles strengthens the mangrove ecosystem's importance as an ideal habitat for estuarine crocodiles. Besides providing space for their living, the mangrove area can provide food with various biota that lives in this area. Other studies suggest that estuarine crocodiles also eat mangrove crabs, fish, water birds and even primates such as long-tailed macaques.

At present, the presence of mangroves in Rungkut District tends to decline with 
the change in the area to a residential area. The results of a study on percentage on mangrove cover in the eastern coast of Surabaya showed an increase in the mangrove area of $67 \mathrm{ha}$, which is the highest cover in the Mulyorejo district. The increase of mangrove area in Mulyorejo District (157 ha) outperformed other areas, then the lowest increase in Rungkut District by 25 ha (Syamsu, Nugraha et al. 2018). By paying attention to the existence of mangroves, conservation of the biota in them is also a must. Tourism activities and land change need to pay attention to the presence of wild animals that are increasingly eroded and threatened with extinction from their habitats.

Currently, Crocodylus porosus is one of the crocodiles included in Appendix II CITES, which allows it to be developed and traded. Holding and breeding activities have also been widely carried out in Indonesia with the generated economic benefits quite attractive. Several crocodile farms can be found in Samarinda (Ripai and Kamarubayana 2016), Balikpapan (Diana, Ardianto et al. 2014), Subang (Catur Setyawatiningsih 2012), Serang (Nuryanti 2013), Medan (Ramadhani 2019) dan Gresik (Najikh 2013). However, the community is still wary of the incidence of conflict between humans and wildlife, especially crocodiles, reported in many regions (Amarasinghe, Madawala et al. 2015, Brackhane, Webb et al. 2018, Das and Jana 2018, García-Grajales and Buenrostro-Silva 2019). It is hoped that this case is not an excuse to catch and even kill wildlife, but it is hoped that it will provide space and attention to the wildlife that is currently still found in Indonesian.

This report of the crocodile Crocodylus porosus estuary from a traditional pond area in Wonorejo, Surabaya shows that there are still wild animals that need support in space and habitat. The Wonorejo mangrove area is expected to become an important wetland area in Surabaya as a place for living and surviving many of Indonesia's tropical natural resources. Changes in mangrove areas are expected to pay attention to long-term impacts and the potential loss of invaluable natural resources.

\section{ACKNOWLEDGMENTS}

Our gratitude delivered to the Wonorejo Mangrove Farmer group for sharing information and educating the community to carry out mangrove conservation activities with sustainable programs. Our gratitude also delivered to the Center for East Java Conservation of Natural Resources Agency for providing data support on wildlife in the Wonorejo mangrove ecosystem, which is an important wetland area in East Java.

\section{References}

Amarasinghe, A. T., M. B. Madawala, D. S. Karunarathna, S. C. Manolis, A. de Silva and R. Sommerlad (2015). "Humancrocodile conflict and conservation implications of saltwater crocodiles Crocodylus porosus (Reptilia: Crocodylia: Crocodylidae) in Sri Lanka." Journal of Threatened Taxa 7(5): 7111-7130.

Anggraeni, I. W. S., D. Rinaldi and A. Mardiastuti (2013). "Population and habitat of longtailed macaque (Macaca fascicularis) in Wonorejo Mangrove Ecotourism, Surabaya." Bonorowo Wetlands 3(2): 101113.

Brackhane, S., G. Webb, F. M. Xavier, M. Gusmao and P. Pechacek (2018). "When conservation becomes dangerous: 
Journal of Aquaculture Science

DOI: https://doi.org/10.31093/joas.v6i2.188
October 2021 Vol 6 (2): 110-114

Online pada http://ioas.co.id
Human-Crocodile conflict in Timor-Leste." The Journal of Wildlife Management 82(7): 1332-1344.

Britton, A. R., R. Whitaker and N. Whitaker (2012). "Here be a dragon: exceptional size in a saltwater crocodile (Crocodylus porosus) from the Philippines." Herpetological Review 43(4): 541-546.

Carpenter, K. and V. Niem (2001). "FAO species identification guide for fishery purposes. The living marine resources of the Western Central Pacific. Volume 6. Bony fishes part 4 (Labridae to Latimeriidae), estuarine crocodiles, sea turtles, sea snakes and marine mammals."

Catur Setyawatiningsih, S. (2012). "Pengelolaan Penangkaran Buaya Muara (Crocodylus porosus Schneider) di Desa Blanakan, Subang, Jawa Barat."

Das, C. S. and R. Jana (2018). "Human-crocodile conflict in the Indian Sundarban: an analysis of spatio-temporal incidences in relation to people's livelihood." Oryx 52(4): 661-668.

Diana, L., D. T. Ardianto and E. Srisanto (2014). "Perancangan Film Dokumenter Tentang Kehidupan Buaya di Penangkaran Teritip Balikpapan." Jurnal DKV Adiwarna 1(4): 11.

García-Grajales, J. and A. Buenrostro-Silva (2019). "Assessment of human-crocodile conflict in Mexico: patterns, trends and hotspots areas." Marine and Freshwater Research 70(5): 708-720.

Hines, J. and M. O. Gessner (2012). "Consumer trophic diversity as a fundamental mechanism linking predation and ecosystem functioning." Journal of Animal Ecology: 1146-1153.

Iskandar, D. (2000). Turtles and Crocodile of Indonesia and Papua New Guinea, PAL Media Citra Bandung.

Kurniati, H. (2008). "Pembesaran dan Penangkaran Buaya Jenis Buaya Muara Crococodylus porosus dan Buaya Air Tawar Irian Crocodylus novaeguineae." 24 p.

Najikh, M. (2013). Perancangan pusat pembudidayaan dan wisata penangkaran buaya di Kabupaten Gresik, Universitas Islam Negeri Maulana Malik Ibrahim.

Nuryanti, R. Y. (2013). "Teknik Penangkaran Buaya Muara (Crocodylus Porosus) Di Penangkaran Taman Buaya Indonesia Jaya, Serang, Bekasi, Jawa Barat." Skripsi. Institut Pertanian Bogor. Bogor.

Ramadhani, F. (2019). "Keanekaragaman Jenis Burung di Kawasan Penangkaran Buaya Asam Kumbang Kecamatan Medan Selayang Kota Medan."

Ripai, A. and L. Kamarubayana (2016). "Penangkaran Buaya Muara (Crocodylus porosus) di PT Makmur Abadi Permai Samarinda." Agrifor 15(2): 155-170.

Saragih, G., M. Hidayatullah and D. Hadi (2020). A preliminary study on the population and habitat of saltwater crocodile (Crocodylus porosus) in Timor Island, East Nusa Tenggara. IOP Conference Series: Earth and Environmental Science, IOP Publishing.

Suwarti, M., Y. A. Mulyani and A. P. Kartono (2018). "Characteristics of Javan Coucal (Centropus nigrorufus) Preferential Habitat in Wonorejo Surabaya." Media Konservasi 23(2): 94-202.

Syamsu, I. F., A. Z. Nugraha, C. T. Nugraheni and S. Wahwakhi (2018). "Kajian perubahan tutupan lahan di ekosistem mangrove Pantai Timur Surabaya." Media Konservasi 23(2): 122-131.

Thorbjarnarson, J. B. (2010). "American crocodile Crocodylus acutus." Crocodiles. Status survey and conservation action plan: 46-53.

Webb, G. J., S. C. Manolis and M. L. Brien (2010). "Saltwater crocodile Crocodylus porosus." Crocodiles. Status Survey and Conservation Action Plan. Third Edition, ed. by SC Manolis and C. Stevenson. Crocodile Specialist Group: Darwin: 99113.

Whitaker, N. (2008). "Survey of Human/Crocodile Conflict in the Union Territory of the Andaman Islands, Hut Bay, Little Andaman, January 2008." Madras Crocodile Trust: Madras. 